\title{
17
}

\section{Modeling the Stormwater Benefits of Green Roofs in the City of Toronto}

\section{James Li}

Stormwater best management practices (BMPs) provide a number of tools to reduce the quantity and improve the quality of stormwater runoff at the source, along the drainage system and at the drainage outlet. These include devices such as downspout disconnection, stormwater gardens, green roofs, rain barrels, infiltration trenches, stormwater exfiltration/filtration systems, sand filters, bio-retention areas, wet and dry detention ponds, and constructed wetlands (Banting et al. 2005). Most end-of-pipe BMPs require a significant amount of land to host them, which is not generally available in downtown urban environments. The opportunity for green roofs to act as source level viable BMPs is logical in cities such as Toronto, since flat rooftops recreate the open space, previously at ground level, that has otherwise been eliminated for vegetation (Jennings et al. 2003). This chapter focuses on green roofs and presents a case study of the stormwater and combined sewer overflow control benefits of implementing GRT over the City of Toronto (Banting et al 2005).

Green roof technologies (herein after GRT) are not totally new and can be defined as a green space created by adding layers of growing medium and plants on top of a traditional roofing system. This should not be confused with the traditional roof garden, where planting is done in freestanding containers and planters, located on an accessible roof terrace or deck. GRT have been around in different forms all over the world for years and their insulative qualities have been used to keep dwellings cool in Tanzania, and

Li, J. 2008. "Modeling the Stormwater Benefits of Green Roofs in the City of Toronto." Journal of Water Management Modeling R228-17. doi: 10.14796/JWMM.R228-17.

(C) CHI 2008 www.chijournal.org ISSN: 2292-6062 (Formerly in Reliable Modeling of Urban Water Systems. ISBN: 978-0-9808853-0-9) 
warm in Scandinavia. The stormwater performance of GRT is dependent upon the soil substrate and the vegetation which in combination provide interception, storage, evapo-transpiration, and attenuation of stormwater.

There are two categories of GRT. Intensive GRT are characterized by deep substrate (greater than $300 \mathrm{~mm}$ ) and large vegetations (e.g. shrubs and trees) while extensive GRT are characterized by shallow substrate (less than $300 \mathrm{~mm}$ ) and ground covering vegetation (e.g. sedum and turf). Extensive GRT are primarily used in existing buildings with structural limitations. Based on the Ontario Building Codes's loading requirements, Au (2007) estimated the maximum substrate depth of extensive GRT for residential, commercial, and industrial buildings in Ontario are $150 \mathrm{~mm}, 200 \mathrm{~mm}$, and $200 \mathrm{~mm}$ respectively. Intensive GRT are usually designed for new buildings as the loading support can be incorporated in the structural design of the new buildings. For instance, the Isuzu dealership building in Singapore has a SUV driving test range on the top of the six storey building with $1 \mathrm{~m}$ depth substrate and safari vegetations. Extra structural support was incorporated into the structural design of the building.

Studies have shown that GRT could provide both quantity and quality control of storm runoff in urban areas (Dramstad et al. 1996; Graham and Kim 2003; TRCA 2006). While greenroofs may not provide adequate control over large storms, they have the ability to intercept, store, and attenuate most of the moderate and small events ( $\mathrm{Li}$ 2006). Thompson (1998) found that a typical extensive GRT can retain 60 to $100 \%$ stormwater. According to the Zinco planning guide (1998), GRT are expected to retain $70-90 \%$ and $40-50 \%$ stormwater during the summer and winter months respectively. Liesecke $(1993 ; 1998)$ estimated that a GRT of 2 to $4 \mathrm{~cm}$ and $60 \%$ of substrate can retain $40-50 \%$ and $60 \%$ of the annual rainfall respectively. Based on a 15 -month field monitoring results, Liptan et al. (2003) found that $69 \%$ of the rainfall was retained by a GRT. Jennings et al. (2003) and Rowe et al. (2003) found that a GRT can retain up to 100\% of rainfall volume dependent upon the volume, intensity, and interevent time of rainfall events. Additionally, Jennings et al. (2003) and Liu (2003) found that a GRT can also attenuate the peak flow of a light rain $(19 \mathrm{~mm}$ in $6.5 \mathrm{~h})$ to up to almost 95 minutes.

While the above research studies have indicated the stormwater control performance of a GRT, there are not many studies that focus on their performance on a watershed basis. Marshall Macklin Monaghan Ltd. (2004) developed HSPF's Unit Response Functions (URF) of GRT using the 2003 field monitoring data of the York University GRT (TRCA 2006). Using the HSPF's URF of GRT, Aqua Beech Inc. (2004) simulated the effectiveness 
of implementing GRT within the Markham Branch of Highland Creek and found annual runoff volume could be reduced by 5\%. Casey Trees and LimnoTech (2007) developed a green build-out model to quantify the stormwater management benefits of trees and green roofs in Washington, DC. A methodology to estimate the stormwater benefits of greenroofs in the City of Toronto, Ontario, Canada is described below.

\subsection{Methodology}

\subsubsection{Identification of GRT Potential in Toronto}

At the time of study, it was necessary that an eligible building be defined for green roof application. Green roof application was considered viable for (i) "flat roof" with slopes less than $2 \%$; (ii) buildings with roof area great than $350 \mathrm{~m}^{2}$; (iii) areas other than underground parking garages or at grade level; and (iv) roofs with at least $75 \%$ roof area available. It was also assumed that the minimum thickness of a green roof was $150 \mathrm{~mm}$.

After the review of other studies on green roofs' benefits and costs, it was decided that a Geographic Information System (GIS) environment be utilized to identify buildings suitable for green roofs and analyze their associated benefits and costs in Toronto. Digital data of buildings, sewer networks, aerial photographs, sewershed boundaries, land use, roads, and spot elevations were provided by the City of Toronto's Works and Emergency Services Department. These data were checked using digital orthophotographs supplied by the City and standardized in an ArcMap 9.0 format. Criteria used to select appropriate buildings include the available roof area ( $>60 \%$ of total roof area), age of buildings (for loading consideration), and type of buildings. For each land use (residential, commercial, and industrial), sample neighbourhoods are selected for GRT implementation. Using these, the total area available for installation of green roofs was aggregated using GIS over subwatersheds and watersheds.

\subsubsection{Modeling of Stormwater Benefits}

The approach to quantify the stormwater benefits of GRT in Toronto was based on the HSPF's URF of GRT (Aqua Beech Inc. 2004) and the aggregation of these URF using GIS throughout the whole city. A URF was defined as the hydrological response of 1 ha test catchment, representing a 
particular land use type, soil, and connectivity configuration with sewers, associated with a certain set of meteorological conditions. The URF of GRT for different land uses were simulated in HSPF using a pervious and an impervious land segments. The total runoff consists of the surface runoff and the net outflow from the infiltrated portion of the precipitation. Table 17.1 shows the land use categories used in the study and the annual runoff with and without green roofs. These URF were estimated by:

- adopting the URF generated in the Highland Creek case study if there was a corresponding land use category; or

- averaging the unit response functions generated in the Highland Creek case study if there were a few similar land use categories

The URF were applied across the City of Toronto by assigning predicted runoff, based on records of usable roof areas, for each land use in each subwatershed. GIS then enabled summing of the stormwater diversions for watersheds and for the whole City of Toronto to demonstrate the reduced demands on the stormwater drainage network hydrologically.

Three types of the stormwater benefits were considered:

- saving of other stormwater BMPs due to the application of green roofs;

- pollutant reduction; and

- reduction of receiving stream erosion.

After reviewing the best management practice bundles used in the Toronto Wet Weather Flow Master Plan (2003), three types of BMPs with higher costs might be substituted by green roofs in a generic manner. They were pervious pavements in residential highrise and commercial areas and underground storage in commercial area. Table 17.2 shows the unit costs of BMPs, which may be substituted by green roofs. This table was derived from the unit costs of BMPs including maintenance in the Toronto Wet Weather Flow Master Plan while the cost saving was the difference in unit costs between green roofs and other BMPs. The total area of green roofs and the unit cost savings of best management practices in Table 17.2 were used to determine the saving of other BMPs by green roofs.

The pollutant reduction benefit $(\mathrm{P})$ and erosion benefit $(\mathrm{E})$ were estimated using the following equations in the City of Waterloo's green roof study (Totten Sims Hubicki 2004).

$$
\begin{aligned}
& P=0.5 * \$ 5,460 / \text { ha_of_greenroof } \\
& E=\$ 5,055 * \text { ha_of_greenroof }
\end{aligned}
$$


Table 17.1 Unit response functions for runoff calculations.

\begin{tabular}{|c|c|c|}
\hline Land Use Description & Runoff-No Greenroof, $\mathrm{m}^{3} / \mathrm{ha}$ & Runoff-With Greenroof, $\mathrm{m}^{3} /$ ha \\
\hline Commercial & 6019 & 4913 \\
\hline Commercial Bigbox & 6223 & 5067 \\
\hline Commercial Downtown & 6019 & 4913 \\
\hline Commercial-industrial & 5742 & 4912 \\
\hline Commercial-residential & 4054 & 3480 \\
\hline Commercial Strip Mall & 6210 & 5063 \\
\hline Educational/Institutional & 2222 & 1827 \\
\hline Greenspace: parks & 875 & 729 \\
\hline Industrial & 5260 & 4757 \\
\hline Industrial Bigbox & 5260 & 4757 \\
\hline Resource-Industrial & 4571 & 4070 \\
\hline Prestige Industrial & 4571 & 4070 \\
\hline Resource-Industrial & 2723 & 2400 \\
\hline Open Space -golf & 653 & 534 \\
\hline Open hydro corridor & 875 & 729 \\
\hline Open Space/Park Land & 875 & 729 \\
\hline Open TRCA land & 430 & 339 \\
\hline Open Valley Lands & 430 & 339 \\
\hline Park & 875 & 729 \\
\hline Residential, open area & 1254 & 1254 \\
\hline Residential High Density & 2415 & 2415 \\
\hline Residential High Rise & 3305 & 3060 \\
\hline Residential Low Density & 1254 & 1254 \\
\hline Residential Medium Density & 1897 & 1897 \\
\hline Residential, open area & 1254 & 1254 \\
\hline Commercial & 6019 & 4913 \\
\hline Government-Institutional, o & 1254 & 1254 \\
\hline STP, Park, commercial-indust & 2501 & 2205 \\
\hline Government-Institutional, $\mathrm{z}$ & 1254 & 1254 \\
\hline Downsview airport & 1386 & 1313 \\
\hline Highway Corridors & 1078 & 1078 \\
\hline Roadways & 1078 & 1078 \\
\hline
\end{tabular}


Table 17.2 Comparison of unit costs of best management practices and estimation of cost saving of green roofs.

\begin{tabular}{|c|c|}
\hline Type of BMPs & Total cost $(\$ / h a)^{*}$ \\
\hline Rooftop gardens for strip mall & 65800 \\
\hline Rooftop gardens for big box & 104800 \\
\hline Rooftop gardens for downtown & 183780 \\
\hline Residential high density foundation drain disconnection & $265010^{* *}$ \\
\hline Residential highrise and institution pervious pavement/parking & $398720^{* *}$ \\
\hline Commerical underground storage & 14400 \\
\hline Commercial pervious pavement in parking & $151030^{* *}$ \\
\hline \multicolumn{2}{|c|}{$\begin{array}{l}\text { Note: The above unit costs were used in the Toronto Wet Weather Study. }{ }^{*} \text { Total cost includes capital } \\
\text { and O\&M over } 50 \text { years. }{ }^{* *} \text { based on } 80 \% \text { imperviousness }\end{array}$} \\
\hline GRT for mall and big box & 85300 \\
\hline GRT for downtown & 183780 \\
\hline Average GRT & 134540 \\
\hline BMP with higher costs than GRT & Unit cost \\
\hline Residential highrise and institution pervious pavement/parking & 398720 \\
\hline Commerical underground storage & 144040 \\
\hline Commercial pervious pavement in parking & 151030 \\
\hline Green roofs & 134540 \\
\hline BMP substitution & $\begin{array}{l}\text { Unit cost saving (\$/ total } \\
\text { ha) }\end{array}$ \\
\hline Low estimate of BMP saving (Commerical underground storage) & 9500 \\
\hline High estimate of BMP saving (Residential highrise pervious pavement) & 264180 \\
\hline BMP substitution & $\begin{array}{c}\text { Unit cost saving ( } \$ / \text { ha of } \\
\text { GRT) }\end{array}$ \\
\hline Low estimate of BMP saving (Commerical underground storage) & $570 * * *$ \\
\hline High estimate of BMP saving (Residential highrise pervious pavement) & $15850 * * *$ \\
\hline
\end{tabular}

\subsubsection{Modeling of Combined Sewer Overflow Reduction Benefits}

Combined sewer overflow (CSO) reduction benefit was estimated by determining the reduction of storage required for the control of CSO in Toronto. The City of Toronto has developed a continuous simulation model (i.e. QQS model) to simulate the CSO condition. Using the QQS model, it 
was predicted that the total annual CSO volume to Black Creek, Humber River, West Don River, Massey Creek, Lower Don River, Western Beaches, Inner Harbour, Eastern Beaches, and Scarborough Lake would be $10,187,056 \mathrm{~m}^{3}$. The total CSO drainage area is 9100 ha. It was also recommended in the Toronto Wet Weather Flow Master Plan (2003) that underground storage of $258,955 \mathrm{~m}^{3}$ be required for the whole CSO area.

The QQS is a detailed continuous model which simulates the combined sewer network for the whole city. For planning level analysis of greenroof's effect on CSO, a simplified approach was used in this study. It was based on analytical probabilistic models, SUDS, which transformed the probability density functions (pdf) of rainfall event characteristics (e.g. volume, duration, and interevent time) into pdf of overflow characteristics (Adams and Fabion 2000). These models were used to estimate the stormwater and CSO conditions at the 17 Canadian Great Lakes Remedial Action Plan areas (CH2M 1993). SUDS provides continuous analysis of rainfall, runoff, and overflows in urban drainage systems and has been found to provide results in good agreement with continuous simulation models such as STORM and SWMM. SUDS was calibrated with QQS's results and then used to estimate the reduction of underground storage.

The method to estimate the reduction of underground storage after the implementation of green roofs was based on the following assumptions:

- the whole CSO area was assumed to be one sewershed for modeling purposes; and

- it was assumed that green roof could replace a minimum $5 \%$ and a maximum $15 \%$ of the total impervious area in the combined sewer area.

With the assistance of the city's modelers, the QQS model was re-run for the $5 \%$ and $15 \%$ scenarios.

The SUDS model was first calibrated to produce the total annual CSO volume of $10,187,056 \mathrm{~m}^{3}$ (predicted by QQS). Table 17.3 summarizes the input and calibrated data for the SUDS model. The SUDS model was then used to simulate the following scenarios:

1. existing CSO condition without green roof;

2. existing $\mathrm{CSO}$ condition with $5 \%$ green roof;

3. existing CSO condition with $15 \%$ green roof;

4. future CSO condition with the Toronto Wet Weather Study's recommended underground storage;

5. future CSO condition with the Toronto Wet Weather Study's recommended underground storage and $5 \%$ green roof; and 
6. future CSO condition with the Toronto Wet Weather Study's recommended underground storage and $15 \%$ green roof.

The CSO benefit of green roofs was estimated by the reduction of underground storage for the same level of CSO control and a unit cost of $\$ 1,340 / \mathrm{m}^{3}$ for underground storage (TWWFMP 2003).

Table 17.3 Input and calibrated data for the SUDS model.

\begin{tabular}{lll}
\hline Input and calibrated data & Value & Details \\
\hline Total CSO area & $9,106 \mathrm{ha}$ & QQS model input \\
Depression storage & $4 \mathrm{~mm}$ & Assumed parameter \\
Pervious runoff coefficient & $25 \%$ & Assumed parameter \\
\% Imperviousness & $51 \%$ & Calibrated parameter \\
Effective interceptor capacity & $0.152 \mathrm{~mm} / \mathrm{hr}$ & Estimated parameter \\
Existing CSO storage & $0.135 \mathrm{~mm}$ & Calibrated parameter \\
Proposed CSO storage & $2.84 \mathrm{~mm}$ & Toronto Wet Weather Study \\
Unit cost of CSO storage & $\$ 1,340 / \mathrm{m} 3$ & Toronto Wet Weather Study \\
\hline
\end{tabular}

\subsection{Results and Discussions}

\subsubsection{Potential Green Roof Area}

Using the methodology in Section 17.1.1, the potential green roof area in the City of Toronto was estimated to be 4984 ha or $8 \%$ of the total land area of Toronto (Table 17.4).

Table 17.4 Available areas for green roof implementation.

\begin{tabular}{ll}
\hline Category & $\begin{array}{l}\text { Area in hectares } \\
\text { (percent in bracket } \\
\text { is of the total land area) }\end{array}$ \\
\hline Total estimated Land Area of Toronto & 63,175 \\
Total Building roof area & $13,478(21 \%)$ \\
Total Building roof area available for greening - flat roofs & $4,984(8 \%)$ \\
greater than 350 sq. m. and 75\% green roof coverage & \\
\hline
\end{tabular}




\subsubsection{Stormwater Benefits}

Based on a 4,984 ha of potential green roof implementation, the stormwater benefits were estimated to be:

- a BMP infrastructure saving from $\$ 2.8$ to $\$ 79$ million;

- a pollutant reduction benefit of $\$ 14$ million; and

- savings from erosion control measures of $\$ 25$ million

The total stormwater benefit could range from $\$ 42$ to $\$ 118$ million.

\subsubsection{Combined Sewer Overflow Reduction Benefits}

Based on the SUDS model simulation, the existing and future CSO volumetric controls were determined to be $17.4 \%$ and $59.7 \%$ respectively (Table 17.5). With $5 \%$ and $15 \%$ of potential green roofs, the existing CSO volumetric control could be improved by $17.8 \%$ and $18.8 \%$ respectively. To achieve the future $59.7 \%$ volumetric control, the reduction of underground storage due to $5 \%$ and $15 \%$ of potential green roofs were estimated to be $11,712 \mathrm{~m}^{3}$ and $34,752 \mathrm{~m}^{3}$ respectively. The total infrastructure saving for $5 \%$ and $15 \%$ of potential green roofs could be $\$ 15.7$ million and $\$ 46.6$ million respectively. If the proposed underground storage were to be built in addition to the proposed GRT in Toronto, the average annual number of $\mathrm{CSO}$ and the average annual percent of runoff controlled could be improved by $1.3 \mathrm{CSO}$ reductions and $2.3 \%$ volumetric reduction respectively. These reductions of CSO could result in additional benefits such as reduction of beach closure and/or other environmental benefits.

Table 17.5 Analysis of CSO scenarios using the SUDS model.

\begin{tabular}{|c|c|c|}
\hline Analysis Scenarios & $\begin{array}{l}\text { Average annual number of } \\
\text { CSO (\#/year) }\end{array}$ & $\begin{array}{l}\text { Average annual \% of } \\
\text { runoff volume controlled }\end{array}$ \\
\hline $\begin{array}{l}\text { 1) Existing condition without the } \\
\text { recommended underground storage }\end{array}$ & 34.1 & 17.4 \\
\hline 2) with $5 \%$ green roof & 34.0 & 17.8 \\
\hline 3) with $15 \%$ green roof & 33.5 & 18.8 \\
\hline $\begin{array}{l}\text { 4) Future condition with the } \\
\text { recommended underground storage }\end{array}$ & 16.6 & 59.7 \\
\hline 5) with 5\% green roof & 16.2 & 60.8 \\
\hline 6$)$ with $15 \%$ green roof & 15.3 & 63.0 \\
\hline \multicolumn{3}{|c|}{$\begin{array}{l}\text { Note: Existing condition refers to the current CSO situation without the Toronto Wet Weather } \\
\text { Study's recommended underground storage. } \\
\text { Future condition refers to the future CSO situation with the Toronto Wet Weather Study's } \\
\text { recommended underground storage. }\end{array}$} \\
\hline
\end{tabular}


It should be noted that a separate model was used to study the impacts of green roof on CSO. The $15 \%$ potential green roof is close to the $100 \%$ green roofing assumption made for the other benefits.

\subsection{Conclusions}

Roofs in urban cities represent large impervious areas of unused space. With increasing concern over stormwater impacts after urbanization, these large areas can be retrofitted to provide stormwater management benefits. There are needs to quantify the stormwater benefits of greenroofs as more cities are in the process of setting up stormwater utilities. While there are many studies (based on either monitored sites or computer simulations) on the stormwater performance of GRT at individual buildings, there are few studies which determine their overall performance on a watershed basis. The study describes in this chapter is an attempt to model the stormwater benefits on a citywide basis using GIS and the HSPF model. The URF is a consistent approach to model the stormwater reduction of GRT on a watershed basis. It depends on the land use, soil, and connectivity configuration with sewers associated with a certain set of meteorological conditions. While the linear assumption of URF may not be appropriate for peak flow calculations, it may be acceptable for annual runoff volume calculations.

Modeling the combined sewer overflow reduction across the City of Toronto is challenging as the detailed QQS model requires a fair amount of time to develop. For preliminary analysis of combined sewer overflows, the SUDS has been found to provide consistent simulation results. The calibrated SUDS can be used to simulate combined sewer overflow reduction due to green roof implementation on a watershed basis.

Last but not least, GIS provides an efficient platform to screen potential greenroofs in different land uses.

\section{Acknowledgment}

This study could not have been completed without the generous support of the following organizations:

- Ontario Science of Excellence, Centre for Earth \& Environmental Technology;

- City of Toronto;

- Federation of Canadian Municipalities; and 
- Natural Science and Engineering Research Council.

The study is part of a project jointly conducted by Doug Banting, Hitesh Doshi, Paul Missios, the author, and three graduate students (Angela Au, Beth Anne Currie, and Michael Verrati).

\section{References}

Adams B.J. and Fabian P. 2000. Urban stormwater management planning with analytical probabilistic models, John Wiley Sons Inc.

Aquafor Beech Inc. 2004. Technical Memorandum on HSP-F Modelling of Green Roofs - Markham Branch of Highland Creek. Report prepared for the Toronto and Regions Conservation Authority.

Au, A. 2007. Simulation Of The Stormwater Reduction And Energy Saving Benefits Of Urban Greenroofs. Msc Thesis, Environmental Applied Sciences And Management Program, Ryerson University, Toronto, Ontario, Canada.

Casey Trees and LimnoTech. 2007. The Green Build-out Model: Quantifying the Stormwater Management Benefits of Trees and Green Roofs in Washington, DC. Report prepared for US EPA, EPA Cooperative Agreement CP-83282101-0, www.caseytrees.org.

CH2M Inc. 1993. Stormwater and CSO control costs of the Canadian RAP sites. Report prepared for the the Government of Canada's Great Lakes Sustainability Fund, Burlington, Ontario, Canada.

Dramstad, W.E., Olson, J.D. and Forman, R.T.T., 1996, Principles in Landscape Architecture and Land-Use Planning, Harvard University Graduate School of Design, Island Press, and American Society of Landscape Architects, Washington D.C.

Graham, P., and Kim, M. 2003. Evaluating the Stormwater Management Benefits of Green Roofs Through Water Balance Modeling, Greening Rooftops for Sustainable Communities Conference, May29-30, 2003; Chicago, Illinois.

Jennings, G., Hunt, B., Moran, A. 2003. A North Carolina Field Study to Evaluate Green roof Runoff Quantity, Runoff Quality, and Plant Growth, ASAE Annual International Meeting, Las Vegas, Nevada, USA, 27-30 July 2003.

Li, J. 2006. Evaluation of Stormwater Performance of Greenroofs in Toronto. Report prepared for the Government of Canada's Great Lakes Sustainability Fund, Burlington, Ontario, Canada.

Liesecke, H. 1993. Wasserruckhaltung bei extensiven dachbegrunungen, Deutscher Gartenbau, 47 (34): 2142-2147.

Liesecke, H. 1998. Das Retentionsvermogen von Dachbegrunungen, Stadt Und Grun, 47:46-53.

Liptan, T. 2003. Planning, Zoning and Financial Incentives for Ecoroofs in Portland, Oregon. Proceedings from Greening Rooftops for Sustainable Communities, First North American Green Roof Infrastructure Conference, May 29-30 ${ }^{\text {th }}$, Chicago. 
Liu, K. 2003. Engineering Performance of Rooftop Gardens Through field evaluation, Proceedings of the $18^{\text {th }}$ International Convention of the Roof Consultants Institute: 13-16 March, 2003, Tampa, FL, pp.93-103.

Marshall Macklin Monaghan. 2004. Technical Memorandum on HSP-F Green Roof URF's. Report submitted to the Toronto and Regions Conservation Authority.

Rowe, D., Rugh, C., Vanwoert, N., Monterusso, M., Russell, D. 2003. Green Roof Slope, Substrate Depth, and Vegetation Influence Runoff, Michigan State University Dept. of Horticulture and Michigan State University Dept. of Crop and Soil Sciences, Greening Rooftops for Sustainable Communities Conferenece, May29-30, 2003., Chicago.

Thompson, A. 1998. Grass-roofs movement in landscape architecture, The magazine of the American Society of Landscape Architects, 88:47-51.

Toronto and Regions Conservation Authority (TRCA). 2006. Stormwater Performance of the York University's Greenroof. Report prepared for the Government of Canada's Great Lakes Sustainability Fund, Burlington, Ontario, Canada.

Toronto Wet Weather Master Flow Plan. 2003. Report prepared for the City of Toronto.

Totten Sims Hubicki. 2004. City of Waterloo's Green Roofs Feasbility Study and City Wide Implementation Plan.

Zinco Roof Gardens. 1997. The Green Roof Planning Guide, Holland, Zinco Inc. 